\title{
Solidary Profit and Efficiency of Love. Motives in Contemporary Catholic Economic Ethics Vojtěch Mašek
}

In October 2015, shortly after the affair of the falsification of Volkswagen cars emission information broke out, Michael Horn, the chief executive officer of the company in the USA, made the following statement: 'The corporation in no meeting has authorized this. This was software

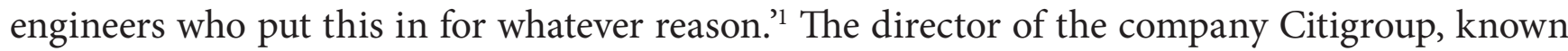
for providing risky loans to insolvent clients at high interest, described the basic message of his work with the words: 'When the music stops playing [meaning solvency] ${ }^{2}$, (...) the situation becomes complicated, but as long as the music is playing you must get up and go dancing. ${ }^{3}$ The two statements bring a practically-minded person to an unambiguous conclusion: to be successful in business one must necessarily behave unethically, and to keep one's moral character one must act 'uneconomically', i.e., against one's own interest and profit. But if one is not content with pragmatic cynicism or empty moral indignation, these statements can stimulate deeper reflection on the possibility of applying morality in the economic sphere and economic rationality in morality, and in that way contribute to a more rounded view of the entirety of human action. The key question of this study will therefore be whether and how an economic ethics is possible in the conditions of the contemporary global market economy and especially what the specific contribution of the Catholic tradition and life in faith for such an ethics consists in.

In order to clarify these two issues, however, one must first come to terms with the phenomenon of ethics as such. And it must be admitted that in the 'postmodern' pluralist society, ethics is by far not a matter of course. It is subjected to constant, and to a great extent justified doubts, queries and debates, which have even lead some humanities scholars to conclude that ethics ought to be crossed out from the list of rational deliberations altogether (Niklas Luhmann, John Caputo) or conceived merely as a project deriving from other disciplines, e.g. from psychology, sociology, philosophy or theology. There is hardly a discipline in the sphere of thinking today that is more underrated than ethics, and yet moral judgment is always first at hand wherever one 'lacks words' in life or when one clashes against the merciless human reality. It is therefore adequate to ask whether knowledge (including the most diverse forms of economic rationality) is always in some sense moral in character, and whether a self-standing 'ethical knowledge' can exist.

What might such knowledge consist in? If one admits that each thinker must always simultane-

1 (c) National Cable Satellite Corporation, Volkswagen Emissions Investigation (on-line), at: http://www.c-span.org/video/?328599-1/ hearing-volkswagen-emissions-violations, accessed $19^{\text {th }}$ July 2016.

2 Author's note.

3 Quoted according to John CASSIDY, Jak selhávají trhy: Logika ekonomických kalamit, Praha: Academia, 2012, p. 18. 
ously 'dwell in the investigated reality', one must to some extent admit that consciousness and conscience are essentially inseparable and that the ethical question concerning the good life is one of the focal points from which rational enquiry starts and to which it must incessantly return. ${ }^{4}$ Despite its fragility and confrontational character, ethics is one of the basic perspectives on reality, striving to attain unity of thinking, speech and action, i.e., the unenforced intrinsic unity of the human person with herself. Ethics defies all attempts to explain reality exclusively from the point of view of functionality and controllability, from the point of view of all-encompassing models of theoretical knowledge or vicariously 'manipulating God', and mercilessly discloses any breach in our personal as well as collectively-institutional trustworthiness. Under the sharp eye of conscience, even an individual celebrated as a "bullet-proof guru" in certain manifestations of craftsmanship or spirit may easily show himself to be a total amateur in the 'art of living', whose inner split undermines the faith of others in the possibility of living their lives (despite all imperfections) as a coherent story. In this way ethics makes it possible to (re)discover the concealed challenge of our personal and collective identity and integrity. ${ }^{5}$

Regarding the question of economic ethics itself, each attempt to find its starting point will always wrestle with two extremes: with the separation of the economy and morality as two entirely disjoint spheres and with their direct identification or deriving one from the other. The former bears upon the establishment of the historical prevalence of a technocratic consciousness in Western civilisation's everyday culture, which in this context is well captured by a statement made by two representatives of the so-called 'games theory', that the methodology of economics is always the same 'whether our players are Attila the Hun or St Francis of Assisi'. 6 The other extreme creates a paradoxical bond between anarcholibertarians, who regard the unconditioned possibility of choice and seeking of an arbitrarily defined own profit as an automatic solution to all economic-ethical problems, and leftist critics of the free market, according to whom contemporary capitalism can be 'morally saved' only if it is deprived of power or annihilated. ${ }^{7}$ The preliminary starting point of this study is that although the market economy and ethics must speak from their own respective positions, they are both anchored in human existence and action as such. Only this original and at the same time historically open unity of economy and humanity (which, of course, can only be captured as a unity in fragility, ambiguity and paradox) makes it possible to make out the sense of economic-ethical thought in our everyday lived experience.

\section{Three dimensions of the morality-economy relationship}

According to many contemporary interpreters, bridging this apparent chasm between the 'factual running' and the moral conception of the market economy is the key to finding the starting point

4 Cf. reflections of the philosopher Michael Polanyi presented in: Jaroslav VOKOUN, Postkritický proud v současné angloamerické teologii, Praha: Vyšehrad, 2009, pp. , 46.

5 According to the hermeneutic philosopher Hans Georg Gadamer, ethical knowledge is specific in that it is always after the 'rightness of life as a whole', that pre-formed items of knowledge or the perfect determination of own goals are never available to it, and nonetheless it must assume responsibility for the fragile temporariness of a momentary human decision. Cf. Hans Georg GADAMER, Problém dějinného vědomí, Praha: Filosofia, 1994, pp. 37-38.

6 Ken BINMORE and Avner SHAKED, Experimental economics: Where next?, Journal of Economic Behavior \& Organization 73/2010, p. 98 (on-line), at: http://www.wiwi.uni-bonn.de/shaked/papers/Binmore-shaked-WhatNext.pdf, accessed $3^{\text {rd }}$ December 2016.

7 For an example of the first kind of attitude, see the interview with the 'anarchocapitalist' Murray Rothbard for the journal The New Banner in 1972, () The New Banner (on-line), at: http://archive.lewrockwell.com/rothbard/rothbard103.html, accessed $27^{\text {th }}$ July 2016. For an instance of the second see Slavoj ŽIŽEK, Požadujme nemožné, Praha: Rybka Publishers, 2011; Geert van ISTENDAEL, Farnost sv. Prekéra: Hospodářská a ekonomická krize - př́ičiny, souvislosti, di̊sledky, Praha: Nakladatelství Lidové noviny, 2014. 
of economic ethics. ${ }^{8}$ However, this requirement must not remain a mere formal proclamation, but must also describe particular ways of putting it into practice. The first clue on the path to this goal may be a hermeneutic description of the dynamics of the mutual bonds between morality and the market economy, which is projected onto our typical everyday human experience and takes the form of a 'strained unity' of three incessantly operative moments of potentiality: 1. symbiosis, 2 . conflict, and 3. transcendence.

The first defies reducing the economy to the external mechanism of profit maximisation, as well as absolutising morality deriving all economic considerations from prior categorically given moral imperatives, and points to the deep mutual interpenetration of morality and economy in everyday practice. It shows how supressed dilemmas of conscience are present even in the apparently most estranged economic operation and how even the most demanding ethical ideals require effective evaluation of powers, opportunities and costs to be realised. This consideration is accompanied by the need for an incessant and parallel intensification of ethical reflection on economic phenomena and a factual knowledge of the functioning of the market economy. The economy and morality converge on the way to ever fuller efficiency and responsibility, and impress on economic ethics not only the mission of being the guide to the good, but also of being the strategic consultant on how it is to be practically achieved. Such a symbiosis is exemplified by various ethical codes and audits, charitable activities of companies, or their cooperation with the non-profit sector.

In the second moment of potentiality the ability of ethics to immediately and efficiently influence economic activity is shown as limited, as is the ability of the economy to deal with the dark and humanly destructive powers it is able to let loose. Here, to act morally means, to a certain extent, to step outside of the economy, while to act economically means to compromise oneself morally. If morality and economy are to maintain their identities, they must oppose each other, without renouncing the common task of transcending human partiality.

In the third moment ethics and the economy meet again, although at the level of sincerely acknowledging their limitations and crisis; the crisis of the economy, where a one-sided 'rationality' can easily make it irrational, and the crisis of ethics, with a rigid moralisation that makes it powerless in its attempts to solve the real problems of economically active people, as well as those who are economically suffering. For example, economics must admit its long-term inability to bear the instability of economic life, especially the irremovable fact of human finitude. Some economic anthropologists believe that precisely this deficiency, disguised by short-circuit ways of overcoming insecurities, is one of the main reasons why market economy systems fail, as can be witnessed at present. ${ }^{9}$ Economics itself can hardly explain the contingencies resulting in economic success and failure, or offer a universal formula for dealing with the general personal and collective crisis of meaning in a life focused on the mere escalation of prosperity. Ethics, on the other hand, has so far been unable to satisfactorily clarify a number of common forms of everyday economic suffering and in general the question is why precisely in economic life people let themselves so easily become crooked, corrupted and estranged and why many honest and enterprising people are so easily humiliated and marginalised in it.

8 See, e.g., Peter SCHALLENBERG - Arnd KÜPPERS (ed.), Interdisziplinarität der Christlichen Sozialethik, Paderborn: Ferdinand Schöningh, 2013; Detlef AUFDERHEIDE and Martin DABROWSKI (ed.), Markt und Verantwortung: Wirtschaftsethische und moralökonomische Perspektiven, Berlin: Duncker \& Humblot, 2015.

9 Cf. the exposition in John CASSIDY, Jak selhávají trhy, pp. 206-207. 
But is the ethical as well as technocratic impotence a merely negative phenomenon, which must immediately be overcome by a new thrust of efficiency and ideals (or ideologies), or is it also a chance to glimpse the limits of our ability to merely consume and evaluate the world and so open up new ways of protecting, sharing and developing it together? Don't true economic ethics arise only in extreme situations in which we are forced to set our own conception of the good life at stake and risk that it will be 'rewarded' by economic failure and insecurity? And do we not attain sustainable prosperity only when profit has ceased to be the only or ultimate goal in life? Enquiring into the economic power of the 'economically powerless' and the economic morality of the apparently 'economically immoral' (e.g. advertising agents or stockbrokers) relieves economics and ethics of their obsessive methodological reductions and opens up an exciting field of new findings of scholarly and practical relevance.

In any case, it holds that all attempts to entirely remove the question of the good life from the economy regularly end in a barren utopia or a destructive tyranny. Even the most complex labyrinths of economic systems and the most impulsive loops of consumer routines make space for manifestations of the greatness, fragility and finitude of our humanity, which must always be reckoned with and at the same time faced in a responsible manner. Can a freedom-loving and economically-perceptive Christianity contribute to that?

\section{The contribution of Christian ethics to economic ethics?}

The second key issue of this study is to describe and justify the possible contribution of Christian and especially Catholic ethics to contemporary market economy ethics. What new and truly specific features are brought into it by the life of faith in its God-given and humanly autonomous forms? According to the main line of its tradition, Catholic ethics certainly does not destroy all that is natural and true, which persons of good will strive for in the economic sphere, and its own message is also permeated by a universal striving for humaneness. Nonetheless, it needs to be asked what Christians can endorse in the economic sphere and what they can share in dialogue with other agents.

Christianity has posed a challenge to the market economy since its historical beginnings, by far not only in the sense of the Calvinist ethics of prosperity as God's favour, as described by the German sociologist Max Weber in his classical work The Protestant Ethic and the Spirit of Capitalism..$^{10}$ According to some contemporary historians and economic anthropologists, the first rudiments of a rational market economy practice appeared as early as in traditional religious communities, especially in the mendicant orders of the late Italian Middle Ages (Franciscans and Friars Minor), albeit set in a broader effort at Christian solidarity, peace and the common good. ${ }^{11}$ At the institutional level, these efforts were expressed by establishing non-usury Christian loan houses, the so-called Montes pietatis, in which the spirit of Christian charity combined with the requirement of their long-term economic sustainability. ${ }^{12}$ In the Renaissance and early modern

10 Max WEBER, Protestantská etika a duch kapitalismu, in: Metodologie, sociologie a politika, Max WEBER, Praha: OIKOYMENH, 2009, pp. 182-223.

11 Cf. Peter SCHALLENBERG, Franziskus, Anstöße zu einer franziskanischen Soziallehre, Köln: Bachem, 2013, p. 13.

12 Cf. Luigino BRUNI and Stefano ZAMAGNI, Zivilökonomie: Effizienz, Gerechtigkeit, Gemeinwohl, Paderborn: Ferdinand Schöningh, 2013, p. 62. 
age, Christian society gradually came to terms with the moral legitimacy of seeking profit, which had previously been condemned with reference to some Gospel passages, and incorporated it in its own message of salvation and ministry. ${ }^{13}$

The arrival of the modern industrial revolution changed the situation irrevocably, when the market economy asserted itself on the whole-society level and Christianity faced the danger of not being able to confront the new moral and social problems implied in that development (dehumanisation of the work environment, cruelty to workers, etc.). The newly arisen situation of mass industrialisation, unregulated enterprise and wage labour is answered by the work of the early personalities of the Catholic social movement and later by Catholic social teaching. But the contemporary process of economic globalisation, described by Pope Benedict XVI as an 'explosion of worldwide interdependence', which the Church wants to confront with solidarity, a rigorous defence of human rights, universal access to technology and knowledge, international trade liberation, development programs, intergenerational protection of the environment and especially the spiritual renewal of every human being's conscience, ${ }^{14}$ poses an equally urgent challenge to Christian social ethics.

My task will now be to show how these traditional challenges and the three moments of a 'natural bond' between ethics and economics are expressed in various currents of contemporary Catholic market economy ethics. Here the concept of Catholic ethics does not denote denominational exclusivity, but the non-power universality of the claim to interpret the particular historical experience with the market economy from the point of view of the fragile wholeness of our redeemed humanity and the dynamic interconnection of Catholic social teaching, thought and practice. ${ }^{15}$ The theological core of this ethics is the renewal of every human being and the whole of humanity by receiving participation in the perfect unity in the diversity of the Persons of the Most Holy Trinity based upon free self-giving. ${ }^{16}$

With respect to the segmentation of the contemporary debate this exposition does not claim to be complete; nonetheless, it strives to capture the main contemporary approaches of Catholic ethics, especially in North America and Germany. I divide these approaches schematically into six groups: 1. Economy of gift, 2. "Gospel of prosperity" (pro-market conception), 3. Social reformism and social market economy, 4. Critical realism and co-responsibility for distant market harms, 5. The micro-ethics of company life, 6. Alternative views. For each of these approaches I will outline its basic contribution to the debate on the meaning of market economy ethics and indicate how they can contribute to bridging the gap between the economy and morality, or economic spirituality.

13 On this interesting historical question see especially Pavel BLAŽEK, Tři dopisy Tomáše Akvinského, Praha: Krystal, 2010. Cf. further Jacques LE GOFF, Peníze ve středověku: Historicko-antropologická studie, Praha: Mladá fronta, 2010, p. 163; Bartolomé CLAVERO, Antropológia Católica de la Economía Moderna, Milano: Giuffrè, 1991.

14 BENEDICT XVI, Caritas in veritate (on-line), at: http://w2.vatican.va/content/benedict-xvi/en/encyclicals/documents/hf_ben-xvi_ enc_20090629_caritas-in-veritate.html, art. 33. Further only CV and section number. Different forms of solidarity in a globalised economy are described especially in the Compendium of the Social Doctrine of the Church, art. 363-367. See PONTIFICAL COUCIL FOR JUSTICE AND PEACE, Compendium of the Social Doctrine of the Church (on-line), at: http://www.vatican.va/roman_curia/pontifical_councils/justpeace/documents/rc_pc_justpeace_doc_20060526_compendio-dott-soc_en.html, art. 363-367. Further only CSDC and section number.

15 CSDC 38.

16 CSDC 34. Cf. Ctirad Václav POSPÍŠIL, Jako v nebi, tak i na zemi: Náčrt trinitární teologie, Praha: Krystal OP, Kostelní Vydř́í: Karmelitánské nakladatelství, 2007, pp. 70-71. 


\subsection{Economy of gift}

The first and probably most influential stream of contemporary Catholic economic thought is the so-called gift economy. This line of thinking is deeply rooted in the Christian theological tradition of interpreting all reality and human existence as a gift of God and at the same time intersects with considerations of economic anthropology and philosophy, pointing to the interconnectedness of exchange, power and gift in the history of economy. ${ }^{17}$ The basic concept of a gift economy is most succinctly expressed by Benedict XVI in art. 34 of his encyclical letter Caritas in veritate of 2009. The experience of gift points to the illusory character of the conviction that human beings are the sole and absolute authors of their economic security and that they can therefore live merely out of feeling their own self-sufficiency and merits. Christian ethics shows that at the root of every economic development there is - besides justice, trust, the common good, or acknowledging every person - also a certain logic of selflessness, which helps to transform even economic relations into relations of brotherhood..$^{18}$ From this the encyclical's author deduces reinforcing the economic role of 'civil society', conceived as a composite sphere of mediation between the private and public sectors and of the merging of private businesses striving for profit with organisations striving for 'human and social goals'. Realising this vision could contribute to an overall 'humanization of the market'. ${ }^{19}$

This conception, also labelled 'civil economy' or 'economy of communion' in art. 46, follows up on that of Stefano Zamagni and Luigino Bruni, Italian theologians and ethicists, as summarised in their book Economia civile of $2004 .{ }^{20}$ Based on the economic model of 'civil humanism' in the Italian Franciscan communities of the late Middle Ages as described by the historian Giacomo Todeschini, these authors develop a conception of economy based on selfless human mutuality (reciprocity) and search for ways of interconnecting it with the common striving for prosperity and contractual equality.

The contribution of the gift economy is twofold: it points out the historical one-sidedness of viewing the modern market economy as a mere sphere of exchange and profit maximisation; and it grounds economic activity in a web of God-human mutuality and inter-human gratitude. Its pitfall is an insufficient reflection of the imperfection of human gift as compared to the gift of God and its ambivalence in particular historical, legal and political contexts (e.g. the relationship of gift and debt, gift and justice, gift and financial responsibility, etc.). That is why some authors try to integrate other elements into the gift economy, e.g. trust, the unpredictable character of free action, or considering the proportion between selflessness and economic prosperity. ${ }^{21}$

17 CSDC 20. Cf. Karl POLÁNYI, Velká transformace, Brno: CDK, 2006; Jacques LE GOFF, Peníze ve středověku; Marcel MAUSS, Esej o daru, podobě a di̊vodech směny v archaických společnostech, Praha: SLON, 1999; () Santa Clara University Information Technology Department, Retrieving Franciscan Philosophy for Social Engagement (on-line), at: http://webpages.scu.edu/ftp/kwarner/Fran-WarnerRetrievingFranciscanPhilosophy.pdf, accessed $19^{\text {th }}$ July 2016.

18 CV 34, 37, 38, 39. See further development of these motives in Daniel K. FINN (ed.), The Moral Dynamics of Economic Life: An Extension and Critique of Caritas in veritate, Oxford: Oxford University Press, 2012.

19 CV 38, 46.

20 Luigino BRUNI and Stefano ZAMAGNI, Economia civile: Efficienza, equità pubblica, Bologna: Il Mulino, 2004.

21 Cf. especially Simona BERETTA, Wealth Creation in the Global Economy: Human Labor and Development, in: Rediscovering Abundance. Interdisciplinary Essays on Wealth, Income, and Their Distribution in the Catholic Social Tradition, ed. Helen ALFORD, Charles M. A. CLARK, Steve A. CORTRIGHT and Michael J. NAUGHTON, Notre Dame: University of Notre Dame Press, 2006, pp. 129-156; Marco BONACKER, Wirtschaftsethik mit theologischem Hintergrund: Interdisciplinäre Notwendigkeit als Chance, in: Interdisziplinarität der Christlichen Sozialethik, ed. Peter SCHALLENBERG and Arnd KÜPPERS, pp. 100-104. On the question of seeking proportion between profit and sustainability in the economy cf. e.g. Anselm GRÜN and Jochen ZEITS, Bůh a peníze: Dialog mnicha s manažerem, Kostelní Vydří: Karmelitánské nakladatelství, 2013, pp. 29-30. 


\section{2 'The gospel of prosperity' (pro-market conception)}

The Catholic pro-market economics of freedom and economic prosperity is represented especially by the thoughts of the American theologian of Slovak descent Michael Novak and his colleagues from the circle of the so-called Acton Institute in the USA (e.g. Robert Siricoe, George Weigel, and others). A broader palette of views deriving from this position is offered, for example, by the collection of papers Catholic Social Teaching and the Market Economy published by the Institute of Economic Affairs in London shortly before the 2007 world economic crisis. ${ }^{22}$ In the conception of Catholic libertarians, the human being is a creative rational being insurmountably affected by sin, whose striving to satisfy one's own interest in a maximally deregulated market must be regarded as morally legitimate. All efforts to politically regulate the economy inhibit human creativity and can result in the rise of political tyrannies based on a utopian vision of the human being. A Catholic must also be maximally wary of any (especially power-asserted) absolute claim of goodness and justice in the economy, of replacing wages with mere social benefits, enterprising activity of the poor by mere redistribution of economic aid or voluntary solidarity by tax obligation. For Catholic libertarians, the free market is the only ethically justified institution capable of developing human freedom, creativity and prosperity. ${ }^{23}$

The main advantages of Catholic libertarianism are its emphasis on practical prudence in economic life and the ability to counter some unrealistic utopias and to take the edge off the (formerly quite pointed) polemics of Catholic social tradition with the constitutional democratic establishment. Its perceptiveness to the positive aspects of 'capitalist' globalisation and its resistance to naive nostalgias after the estate economy of the pre-modern age is also valuable. Its problem is that it downplays the destructive side-effects of the free market in the sphere of financial stability, public goods, culture, education, the environment, or family relationships. Catholic libertarians often overestimate the significance of voluntary morality and non-formal agreements between business people and overlook the necessity of an institutional enforcement of general market rules, typically in the sphere of international investments or speculation in the financial markets. The way they handle human sin as something that the market system must always reckon with and sometimes even 'build' upon is also ethically doubtful in a certain sense. ${ }^{24}$ Catholic social teaching repeatedly points out that sin hinders economic prosperity and development, not facilitates it, and that the sin of economic structures will eventually turn against the personal freedom it was intended apparently to ensure. On the other hand, a moderate regulation of market processes, which is at the same time rigorous in a carefully delineated sphere, can be in the interest of market stability, as has become apparent after the global economic crisis of $2008 .^{25}$

Since some Catholic libertarians dogmatically cling to the idea of market self-regulation it is advantageous to listen also to the more moderate voices in the same camp. Although the American Dominican economist Albino Barrera has devoted most of his works to a many-sided defence

22 Philip BOOTH (ed.), Catholic Social Teaching and the Market Economy, London: The Institute of Economic Affairs, 2007. For a systematic exposition of Novak's theology of the economy cf. especially Roman MÍČKA, Michael Novak a jeho projekt teologie demokratického kapitalismu, Brno: Luboš Marek, 2009.

23 Philip BOOTH, Catholic Social Teaching, pp. 35-37.

24 Cf. Michael NOVAK, A Closet Capitalist Confesses, in: Three in One. Essays on Democratic Capitalism 1976-2000, ed. Edward W. YOUNKINS, Lanham: Maryland, Rowman \& Littlefield Publishers Inc., 2001, pp. 6-12. See further Michael NOVAK, Challenges to Benedict's Vision. 'Sin', in: The Moral Dynamics of Economic Life: An Extension and Critique of Caritas in veritate, pp. 33-36.

25 Cf. Wolf-Gero REICHERT, Unternehmen unter der Dominanz der Finanzmärkte?: Orientierungen aus Sozialethischer Perspektive, AUC Theologica 1/2016, pp. 100-102. 
of the free market as the most effective instrument of distributing goods and of economic globalisation as a stimulus to 'extending moral obligations and responsibility' on a worldwide scale, he can be critical of an absolute glorification of the market as a system of perfect predictability, rationality and freedom and acknowledge also unintended incidental harms (externalities) that the market naturally causes to some vulnerable social groups. ${ }^{26}$ In his book Market Complicity and Christian Ethics of 2011, Barrera distinguishes between four types of such harms: two can be directly associated with human responsibility and co-guilt (enabling for bad actions and a quickened production of superfluous harms) and two only indirectly reflect the inevitable impact of cumulative harm (overlooking the external impacts of one's own economic activity, reinforcing unjust socio-economic practices or institutions). ${ }^{27}$

\subsection{Catholic social reformism and the position of the social-market economy}

Another influential stream of Catholic economic thought is the position taken by advocates of the so-called social market economy, deriving especially from the German tradition. In this context, it is sometimes spoken of as Catholic reformism or the so-called Höffner School (after Cardinal Josef Höffner (1906-1987), an outstanding scholar in the sphere of social ethics). Besides its Thomistic roots, this stream is also close to so-called German Ordoliberalism and to some ideals associated with the origin of the European Union. In the older tradition, it is necessary to distinguish between the purely Ordo-liberal current (Walter Eucken and his pupils), according to which the free market is 'already social' in itself because it increases the universal chances of development, and the 'social-political' current, which requires a more active regulation of the market towards desired social goals (Wilhelm Röpke, Alexander Rüstow and Alfred Müller-Armack). ${ }^{28}$ For the sake of lucidity, my exposition will focus on the conception of Cardinal Reinhard Marx, an advocate of the latter of the two currents, known in the Czech milieu for his book Das Kapital: A Plea for Man of 2008. ${ }^{29}$

In the popularly worded introduction to this book Cardinal Marx on the one hand endorses the traditional von Ketteler's social-reformist vision of the ordering of market economy, which wanted to orient the use of private property to the common good and solve class antagonism between workers and employers by conciliatory collective negotiation, but on the other hand it raises the question as to whether perhaps some diagnostic warnings of the Marxists have also gained a new topicality in connection with the present economic globalisation. ${ }^{30}$ According to Reinhard Marx, the list of serious risks associated with this process includes decreasing the taxation of large businesses and increasing tax payments by normal citizens, the general insecurity of employment (the so-called precariat), the abrogation of the tariff wage system, decreasing employment-legal

26 Cf. Albino BARRERA, Individuating Collective Responsibility, in: Distant Markets, Distant Harms: Economic Complicity \& Christian Ethics, ed. Daniel K. FINN, Oxford: Oxford University Press, 2014, pp. 230-231. Barrera claims that the negative extrinsic impacts of market processes are merely the indirect consequences of the fluctuation of prices and circulation of money in the global market economy (that is why he labels them 'pecuniary externalities'). Cf. ibid.

27 Albino BARRERA, Market Complicity and Christian Ethics, Cambridge: Cambridge University Press, 2011.

28 Cf. Gerhard KRUIP, Tržní hospodářství v katolickém sociálním učení, AUC Theologica 1/2016, p. 28. But the spectrum of Christian attitudes to business ethics in German-speaking countries is much more diverse, as indicated for example by the already mentioned collection Detlef AUFDERHEIDE and Martin DABROWSKI (ed.), Markt und Verantwortung. Wirtschaftsethische und moralökonomische Perspektiven; or again Gerhard Kruip in his paper Gerhard KRUIP, Aktuelle sozialethische Beiträge zu Wirtschaftsethik und Unternehmensethik, Jahrbuch für Christliche Sozialwissenschaften 51/2010, pp. 321-350.

29 Reinhard MARX, Kapitál. Plaidoyer pro člověka, Praha: Academia, 2013.

30 Cf. ibid., p. 24 f. 
protection and pension security, weakening the position of the unions against supranational corporations, deepening the abyss between the rich and the poor, child poverty, unlimited financial speculations at the expense of tax payers, the gradual dissolution of the middle class, heightened competition amongst employees and investment areas, pressure on investment funds for shortterm profit to the detriment of market stability, and one-sided interest policies of international financial institutions, etc. ${ }^{31}$

According to Marx, these problems can be solved by the model of the 'global social market economy', which would ground the economy in a world political order 'oriented at general welfare and providing space for institutionalized solidarity. ${ }^{32}$ It would consist in extending the so-called social state to a global level and at the same time transforming it into a more flexible model, which would allow for an evening out of class opposition and protection against a global increase of market risk, but only to an extent that would allow individuals to be active and take care of private and public matters (Marx, following Alexander Rüstow, speaks of 'vital policy'). ${ }^{33}$ The core value of Marx's economic ethic is human freedom, albeit a freedom conditioned many times by actualising truth through the common good, by personal dignity and 'social accommodation', by the guarantee of freedom for all, by generally binding rules and by constitutionally-democratic state authority. ${ }^{34}$ Its other key value is social justice conceived not only as a pre-requisite of personal freedoms and material security, but also as the general participation of all citizens in the basic transactions of social life. ${ }^{35}$ The market is not the goal in a social economy, but a mere instrument of 'permanent and secure constitution of material conditions facilitating the humanly dignified development of individuals and social systems.' ${ }^{36}$

Following up on the socially oriented current of German Ordoliberalism, Reinhard Marx proposes a number of practical reforms that in his view answer the market economy challenges of the $21^{\text {st }}$ century. These are, for example, the renewal of tariff wage negotiations among government representatives, employers and unions at a global level, ethical audits, managers using their personal property as a guarantee for the harm they have caused, a more effective regulation of 'vulture funds' and financial speculations, the eradication of extreme poverty by development programs (based on long-term 'empowerment to self-sufficiency' as well as direct redistribution to the poorest), opening up markets to developing countries and ecological care in developed ones, personal encounters of the rich and the poor, assistance for poor countries in constructing administration and infrastructure, a boycott of socially irresponsible producers, the creation of a so-called 'third labour market', and the establishment of a global political and economic authority introducing just competition and general participation. ${ }^{37}$

Social market ethics is beneficial by its diagnosis of conflicting moments in ethics and the market and by its critical analysis of the threats of economic globalisation. But at times it is too egalitarian and does not take sufficiently into consideration the question of economic efficiency or the complex character of contemporary economic injustices. For human 'estrangement' in the contemporary world does not arise only from excessive market deregulation, but also from the

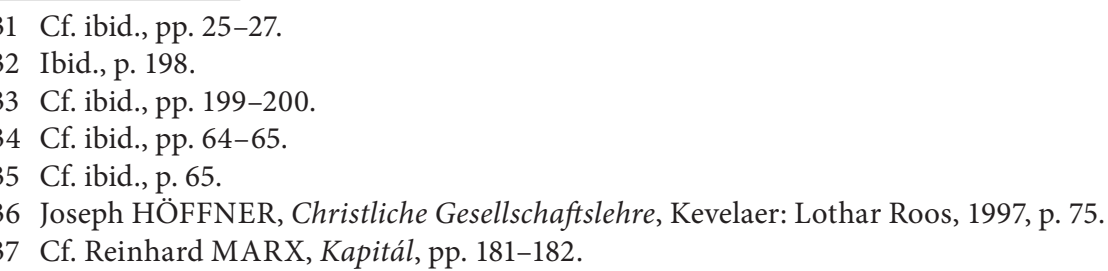


concurrent hypertrophic growth and inefficient civic control of structures of political power and violence.

\subsection{Critical realists and co-responsibility for distant market harms}

The contemporary school of so-called Catholic critical realists, mostly scholars of American and Italian descent (e.g. Daniel K. Finn, Douglas V. Porpora, Margaret Archer, Pierpaolo Donati, and others), is primarily concerned with the specific transformation of human relationships in the context of economic globalisation. Due to the interconnection of markets, technologies and politico-legal institutions, the contemporary economy sustains an ever wider sphere of social relationships based on an impersonal distance between people, indirect relationships or relationships mostly mediated by rules and institutions. This type of relationship multiplies market dependencies and the impacts of our actions on so-called 'distant neighbours', whereby it raises the question of the extent of our moral co-responsibility for so-called distant market harms. ${ }^{38}$ The notion 'critical realists' itself refers to this group's sociological orientation on investigating the complexity of causes of social action expressed with the concept of 'emergence'. Emergence is a special relationship of two elements (in the present case economic agents) which by its 'causal impact' facilitates the emergence of an entirely new reality that does not exist at the level of the individual elements. This fact makes it more difficult to discover the connections between our action and its impact on distant neighbours, and thereby also to evaluate the level of our co-responsibility for global economic decisions. ${ }^{39}$

In this context, critical realists speak of the system-structural grounding of freedom of choice, which complicates, but does not abolish, human responsibility. Our responsibility is merely ever more bound to a phenomenon that can be designated as the 'web effect'. In the market an individual first enters some sort of primary 'closeness web', but through the dynamics of his relationships is indirectly active beyond this web and his moral responsibility is directly proportional to his status and decision-making influence within this web. An example can be the action of a stockbroker, who is not responsible for all speculations done in financial markets but nonetheless must be accountable for his action within the narrower reach of his market transactions. ${ }^{40}$

The crucial question now is whether critical realists, in a justified effort to delineate the limits of our responsibility for economic harms to 'distant neighbours', can be content with the merely abstract scholarly notions of causal impact or web effect (which are not easily demonstrable by experience) and whether they ought not to clarify philosophically first the connection between human freedom and human relationality against the background of our relationship to the world and to history as a whole. Are relationships to 'distant neighbours' merely an extrinsic feature of an objectivistically conceived reality, or are they somehow related to the everyday perception of our apparent powerlessness and impersonality vis-à-vis today's problems of the global economy? And can they, despite their hypertrophied power and routine running, still be conceived as a 'mediated' dimension of our immediate lived experience? Besides this philosophical deficiency,

38 Probably the most complex expert text on this issue formulated from the position of critical realists is the already mentioned collection Daniel K. FINN (ed.), Distant Markets, Distant Harms of 2014.

39 Cf. Pierpaolo DONATI, The Morality of Action, Reflexivity and the Relational Subject, in: ibid., pp. 58-73; Douglas V. PORPORA, Who is Responsible? Critical Realism, Market Harms, and Collective Responsibility, in: ibid., pp. 4-21. These reflections are also at least indirectly related to the Catholic teaching of so-called structural sin.

40 Cf. Pierpaolo DONATI, The Morality of Action, Reflexivity and the Relational Subject, in: Distant Markets, Distant Harms: Economic Complicity \& Christian Ethics, ed. Daniel K. FINN, Oxford: Oxford University Press, 2014, pp. 70-73. 
critical realists must face an objection of a more ethical character. The already mentioned moderate economic theologian Albino Barrera correctly asks in his paper Individuating Collective Responsibility whether an over- vaguely collectivistically conceived responsibility for market harms cannot give rise to the situation where no one will assume responsibility for them and no one will also be able to correct them. One must ask whether other criteria need not be stipulated for evaluating the economic responsibility of particular persons than belonging to the 'relationship web' of a social action, e.g. the mental capacity of agents, their moral conviction, the group of people affected by the harm, and others. ${ }^{41}$

\subsection{Micro-ethics of company life}

But the attention of Catholic economic ethicists does not focus only on the sphere of 'big economy' and global market relations, but also on the ethical problems of particular companies and consumers. Although it is not possible to abstract from the connection between the company sphere and the global market sphere, to some extent it is possible to speak of specific corporative micro-ethical problems. Among Catholic thinkers this emphasis is developed by a whole number of authors, of whom Michael Naughton and Kenneth Goodpaster are probably worth the greatest attention.

Michael Naughton's attitude loosely develops the starting points of the so-called theology of institutions, a special direction of Catholic thought developed in the 1970s as a certain moderate antipode to liberation theology. ${ }^{42}$ From its founder Robert K. Greenleaf (1904-1990), Naughton adopts the valuable concept of servant leadership, the foundation of which is a continuous verification of whether company management strives first of all to secure the 'highest priorities of neighbours', subordinate employees, colleagues, customers, etc. and whether the management allows people to 'develop as [fully-fledged] human persons', i.e., to become more healthy, more free and more capable of serving others by themselves in the future. ${ }^{43} \mathrm{~A}$ servant leader tries to listen, empathise, reflect, grasp problems, predict, persuade and build the company not only as an arena of private interests, but as an integral social community of its kind. ${ }^{44}$

In their book Leading Wisely in Difficult Times Michael Naughton and David Specht argue against the contemporary materialistic and morally relativist conception of company ethics based merely on the personal interests of each individual worker. ${ }^{45}$ The goal of servant leadership is to develop a leading worker's ability to 'see things whole', 'to see their holistic nature as body and soul, material and spiritual, faithful and reasonable, principled and technical'. ${ }^{46}$ Naughton and Specht also ask

41 Cf. Daniel K. FINN, Distant Market, Distant Harms, 2014, p. 238.

42 This theological current is commonly taken to have been founded by Robert K. Greenleaf, whose works were developed by further scholars, e.g. Stephen Covey, Peter Senge, Max De Pree, and others.

43 Cf. Robert K. GREENLEAF, Servant Leadership, A Journey into the Nature of Legitimate Power and Greatness, Mahwah: Paulist Press, 2002, p. 27. Further see Robert K. GREENLEAF, Seeker and Servant, Reflections on Religious Leadership, New York: Jossey-Bass, Inc., 1996.

44 Cf. Robert K. GREENLEAF, Servant Leadership, Introduction, pp. vi-vii. The requirement that a private business - besides a justified effort at making a profit - becomes also a 'solidary community' was also formulated by Pope John Paul II in the social encyclical Centesimus annus (on-line), at: http://w2.vatican.va/content/john-paul-ii/en/encyclicals/documents/hf_jp-ii_enc_01051991_centesimus-annus.html, art. 43. Cf. CSDC 340.

45 In this context authors also speak critically of the relativist style in which managerial economics is currently taught by means of socalled case studies. Michael NAUGHTON and David SPECHT, Leading Wisely in Difficult Times: Three Cases of Faith and Business, Mahwah: Paulist Press, 2011, pp. 7-11.

46 Ibid., Introduction, p. xi. 
how the Christian faith can be expressed in the practical routine of a company manager and they present three typologically different stories of companies that decided to apply it in their objectives and economic activity. These stories combine the leaders' moral character with the ethical cultures of their institutions and transcend the mere sphere of technical competencies and ethical codes. These stories suggest how even the problems of today's complex, competitive and globally interconnected company practice can be read in the perspective of faith, moral courage and good stewardship. ${ }^{47}$

Naughton's colleague Kevin Goodpaster is also concerned with the predominant trends in the organisation culture of contemporary companies and finds three kinds of pathological features in it: fixation or singleness of purpose, 'rationalisation' (rational justification of ethically undesirable activities) and moral split (separating morality in personal and company life). ${ }^{48}$ These are matched by three kinds of ethical imperatives, which must be applied in company culture, viz. the imperative of orientation, institutionalisation and maintaining a 'corporative conscience. ${ }^{49}$ Goodpaster explains the special concept of corporative conscience as a semi-conscious 'mind map' of the economic situation, an ethical intuition of the broader framework of the 'cultural reality' in which (despite the decisions of the individual agents) economic life normally takes place. ${ }^{50}$ Corporative conscience combines the personal character of the entrepreneur with the customs and practices of the company; its role is not merely passive, as it also actively directs action and practical orientation. On the one hand it is a descriptive, diagnostic instrument; on the other hand a prescriptive, normative one. In the latter of these two spheres Goodpaster further finds the discerning, critical and idealising function, which is exercised in determining our values and convictions. ${ }^{51}$

The most delicate point of Goodpaster's account of economic conscience is the relationship between the personal and 'organisational' level. Goodpaster admits that conscience can take the character of a 'shared perspective' and distinguishes between its so-called three polarities: the I-other polarity, the interested-disinterested polarity and the ideal-real polarity. In the first, we break through the 'illusion of our selfishness' by being aware of and respecting our neighbour, while, in the second, we broaden the horizon of our 'we' to transcend the opposition 'we' and

47 Ibid., pp. 4-5. The first story concerns the company Reell, which had to face a 35\% drop in notebook sales income in connection with the American crisis of 2000-2001. Despite serious financial problems, the company decided not to lay off employees and offered them the possibility of a salary decrease graded according to prior level of income, responsibility and merits (upper management decreased their own salaries the most). That enabled them to maintain an atmosphere of community coherence and in a long-term horizon also economic prosperity. The second story describes the behaviour of the company Engineered Products which faced strong market pressures to relocate the production of pressing machines to China. The management openly explained the whole relocation plan, spread over ten months, to the employees, and involved them in deciding about it and helped a section of the employees find work in other companies. They refused to conceal their decision behind the impersonal powers of economic globalisation and acknowledged their responsibility for partial failures that may have affected the relocation. The third story deals with the situation of the company Tomasso Corporation which directly incorporated the values of Catholic social teaching into its company objectives. The most interesting elements of their company culture include, for example, annual bonuses shared by managers and employees, obligatory bi-annual contact with laid-off employees with the goal of the 'reconciliation of differences in opinion', an independent investigation of the organisational climate in the company conducted by an external partner, spiritual ecumenical support groups, bi-annual volunteer social work carried out by employees, space for quiet reflection or prayer before and after important company meetings, and others. Cf. Michael NAUGHTON and David SPECHT, Leading Wisely in Difficult Times, pp. 94-98.

48 Cf. Kenneth E. GOODPASTER, Conscience and Corporate Culture, Malden: Blackwell Publishing, 2007, pp. 25-26. Goodpaster covers these three pathological features with the umbrella concept 'teleopathy', i.e., 'the unbalanced pursuit of purpose' in thoughts, desires and deciding in economic agents, especially managers. Cf. ibid., pp. 28-29.

49 Ibid., p. 7.

50 Ibid., p. 3.

51 Cf. ibid., pp. 34-35. Goodpaster, who further seeks a connection between the concept of conscience as a mind map and Aristotelian prudence (fronésis), shows how his concept relates to the conception of a 'committed agent' in economic games theory, etc. 
'they' and assume the disinterested perspective of 'we all', which corresponds at the ethical level to the so-called golden rule. The third polarity comes into play when we ask how we are aware of ourselves and our neighbours in real practice and how we can actualise our ideal in the real world, which stands up in opposition to it. According to Goodpaster, this level is symbolically captured by the sentence 'That is our life. ${ }^{52}$

\subsection{Alternative views}

Besides these main streams in Catholic economic ethics, at least two creative idea alternatives must selectively be mentioned. In his older but, by its content, still up-to-date study From Business Ethics to the Vocation of Business Leaders the Leuven ethicist Johan Verstraeten begins from the premise that doing business is not merely a purposeful activity oriented to an external economic end (profit), but a peculiar economic and ethical practice..$^{53}$ Business ethics expresses a basic tension between our desires and their limits, imperatives and visions of good life. ${ }^{54}$ Its basic level is investigating company ethos, the factual attitudes, values and behaviour patterns of managers and employees, as well as factual consequences of ethical behaviour in the business sphere. At this level, empirical studies can show to what extent ethical action is economically feasible, even though this index must not be regarded as the only criterion of evaluation. ${ }^{55}$ The second level is normative economic ethics, which must at the same time be practical, because it does not suffice to merely abstractly define the desirable values, for ethics must deal with particular problems, dilemmas, and with the economic activity as a whole. The key method of normative economic ethics is casuistry, which is, of course, justified by general rational argumentation. The third level is practical wisdom, taking into account the individuality of persons and circumstances of economic activity; Verstraeten associates this especially with the ethics of economic organisations. ${ }^{56}$ The fourth level is the ethics of the social responsibility of companies, which Verstraeten conceives as a form of 'corporative citizenship', i.e., a 'contract' made with society as a whole, based on a universal respect for human rights. ${ }^{57}$ Finally, Verstraeten transcends the framework of ethics as such and at the philosophical and theological level asks about the broader conditions of humanising business. ${ }^{58}$

So for Verstraeten business ethics is not a mere pre-defined formula for subsequent correct action, but a complex challenge that 'in light of the tension between norm and reality, vision and limitation, allows for the creation of a "space of freedom"' and 'leads to a choice for the most humane solution possible in the given circumstances'. ${ }^{59}$

A more theological conception of economic ethics is developed by Peter Schallenberg, director of the German Bishops' Conference's Central Advisory Committee for Social Issues (KSZ) in Mönchengladbach. In his extensive introduction to the German edition of the book Economia

52 Ibid., p. 60.

53 Cf. Johan VERSTRAETEN, From Business Ethics to the Vocation of Business Leaders to Humanize the World of Business, Business Ethics. A European Review 2/1998, p. 112.

54 Cf. ibid., pp. 113-114.

55 Cf. ibid., p. 112.

56 Cf. ibid., pp. 113-114. Verstraeten's schema is clearly inspired by the French philosopher Paul Ricoeur's conception of ethics presented in the book Paul RICOEUR, Soi-même comme un autre, Paris: Editions du Seuil, 1990.

57 Cf. Johan VERSTRAETEN, From Business Ethics to the Vocation of Business Leaders, pp. 117-118.

58 Cf. ibid., p. 118.

59 Ibid. 
civile by Bruni and Zamagni, Schallenberg presents an original interpretation of the market economy from the point of view of the Franciscan tradition and Christian eschatology ${ }^{60}$ According to Schallenberg, Franciscan ethics, with its focus on the poor, adopts the biblical emphasis on the 'gradual transformation of the visible world in the presence of the invisible eternity', which can only be perceived in the sacrament of the Church. ${ }^{61}$ The Sermon on the Mount elucidates 'the internal conversion of a mere exchange of justice to love without selfish calculation' and the Creator's love is 'a single all-encompassing yes to the needs of man and his world'. ${ }^{62}$ Markets are also a part of this world, which a Christian should not leave but 'transform them into instruments of [one's own] conversion and improving the world' through individuals who look out for the second coming of Christ. Their biding time takes place with the awareness that Christ has at the same time already come, especially in the poor and the suffering, which arouses a motivation to urgent ethical action in the sense of 'here and now is the last hour of action'. ${ }^{63}$ Therefore Christian economic ethics is 'the world-facing side of eschatology' ${ }^{64}$

\section{Conclusion}

A key article - 331 - of the Compendium of the Social Doctrine of the Church emphasises the intimate relationship between morality and the economy, which makes it necessary to take economic arguments into account in ethics and not only vice versa. ${ }^{65}$ The encyclical letter Caritas in veritate in turn requests that ethics concern 'every phase of economic activity' and its most common manifestations ${ }^{66}$ In the preceding exposition I have shown how the intrinsic relationship of economy and morality is perceived in different conceptions of Catholic economic ethics. The question remains how this requirement is to be actualised in our everyday lived experience.

First it must be admitted that the particular form of this relationship is normally not determined by utopian models of theoretical economists or tribunals of renowned moralists, but by practical decisions of human prudence. Most economic decisions take place in the grey zone of compromise between our moral ideals and the strategic pressures we are subjected to, and are subject to a variable dynamics of personal, work and civic life. As already indicated in the introduction, the most realistic form of Catholic economic ethics can be reached by the analysis of the paradoxical extremes of the moral-economic life, i.e., of the possibility of good action under the pressure of seeking ever increasing profit and the possibility of economic deliberation in a situation of maximum spiritual freedom and solidarity. With these it is possible to associate certain typical roles, which can be represented, for example, by a stockbroker and an ascetic saint acting out of charity. If it is possible to demonstrate that the ethical and economic attitudes are compatible in these extreme positions, then they cannot be ignored even in the everyday reality of life.

The main reason why a stockbroker's job is attractive is the possibility to take the free perspective of a player who is constantly exposed to opportunities for action, to which he receives an instant

60 Peter SCHALLENBERG, Einführung zur deutschen Ausgabe: Die franziskanische Spiritualität und eine christliche Moralökonomie, in: Zivilökonomie. Effizienz, Gerechtigkeit, Gemeinwohl, Luigino BRUNI and Stefano ZAMAGNI, pp. 13-29. Cf. note 9 to this study.

61 Ibid., pp. 20-21.

62 Ibid., pp. 21-22.

63 Ibid., pp. 26-27.

64 Ibid., p. 28.

65 CSDC 331. Article 332 states that efficient production of economic goods is morally obligatory, otherwise resources are wasted.

66 CV 36, 37. 
response. The urgency of action brings along the typical risks of rashness, restlessness, herd mentality, succumbing to passions, and also of moral pragmatism, which excuses a certain level of human inconsiderateness by a lack of time for decision-making. But the recent world financial crisis has shown in full nakedness that even the 'virtual sector' cannot rely merely on mathematical formulas, statistical predictions and momentary intuition, but must be exposed to the piercing light of broader human reality. Concealing the real risks and consequences of speculative transactions in the shared world need not result merely in a breach of trust and interpersonal relations, but also in the quick loss of that wealth and freedom for which habitual players primarily strive.

Despite the differing ethical codes, it is therefore necessary to adopt certain moral brakes that would prevent experienced practitioners from falling into the comfort of cynicism and allow them to face the typical conflicts of interest in a dignified manner, to keep face and maintain the economic efficiency of their work. The British journalist Brian Bloch formulates these brakes as follows: 1 . When in doubt, spell it out; 2 . Look for solutions suited to the human person; 3. Don't wait until the client asks, ask yourself; 4 . Be quite specific concerning the risks of the transaction; 5. Continuously inform the client of the changing situation in the market; 6 . Make sure that the client understands the message. ${ }^{67}$ To these guidelines Catholic ethics adds more demanding requirements: 7. Be free from property and use it to serve; 8 . Ask about the meaning of using goods and share them responsibly; 9. Consider the good of all those affected by your action; 10. Do not damage competitors' dignity, learn from them; 11. Be selfless even when 'acquisitive'; 12. Bear the mundane and look for your vocation in it; 13. Direct others so that they can do their best; 14 . Even in deepest crisis look out for hope and go out to meet it.

On the other hand, even the most sacrificing saint cannot live merely out of the incessant stream of received gifts and miracles, but must necessarily ask what the real human impact of his love and goodness is. Every sincerely loving and spiritually living person is aware of the difficulty arising from the ambiguity of every human action, its possible bad consequences and the many-sided dependence upon the action of others. Radical freedom from property does not exclude but rather requires a rational consideration of what to expend one's abilities, energy and resources on in the limited time there is and how best to conjoin them with the possibilities, intentions and interests of others, who are as fragile, imperfect and mortal as the saint himself. Even the most independent ascetic cannot take for granted that others will automatically understand and accept his attitude, but must humbly expose himself to a discussion over what is good, not only from his point of view but also from the point of view of the community and civil society as a whole. So even the heroism of a saint is not wholly exempt from the requirement of tactical planning, rationality and economic efficiency. ${ }^{68}$

Christian love is at all times simultaneously a challenge to cautiousness and realism, which does not aggrandise our possibilities and 'calculate' with the fact that salvation always comes through human imperfection. Nonetheless, Christian realism is not expressed by moral compromise and

67 () Investopedia, L.L.C., 8 Ethical Guidelines (on-line), at: http://www.investopedia.com/articles/financialcareers/08/broker-ethics-tips.asp, accessed $22^{\text {nd }}$ July 2016.

68 Loosely following up on the French philosopher and Jesuit Michel de Certeau, it is possible to distinguish between the strategy and tactics of 'economic love'. While strategy calculates with the loved one and reinforces the mutual relationship by intentionally balancing out economic security and insecurity, tactics links one's own position to the other's position without wanting to control him. It does not claim what belongs to it in advance, but nonetheless actively looks out for and makes use of momentarily offered opportunities to the common benefit of all for whom one is co-responsible. () Blog la WordPress.com (on-line), at: https://chisineu.files. wordpress.com/2012/10/certeau-michel-de-the-practice-of-everyday-life.pdf, accessed $23^{\text {rd }}$ July 2016. 
a concession to material temptations, but rather by trusting that the Word of God is always a deeper foundation of reality than what is momentarily flaunting itself, including the brutal sways of financial markets and economic injustices. ${ }^{69}$ But it does not slip into a cheap 'spiritualisation' and 'ethicisation' of economic problems either, acknowledging the necessity to confront human imperfection by a prudent placement of legal obstacles and the erection of political institutions controlling the market economy. In this sense, Catholic economic ethics is always simultaneously an ethics of economic freedom as well as a civic and political ethics.

The most difficult task is to formulate its demands in the plurality of stories of our personal and community life, where we must be satisfied merely with a general description of the typical possibilities and dilemmas. Our economic-ethical life is no doubt centred on the question of vocation, in which humanity's search is united with a gift that may stand in tension with our natural abilities and weaknesses. Another aspect is the precarious and incessant search for a balance between family life and work life and also the effort to find personal and shared happiness. The momentary form of that balance is always at the same time a criterion of our economic rationality and respect to our own humanity. This sphere also comprises the search for a prudent and adequate level of property ownership and human consumption.

The third level of conjoining economic and moral life is the sphere of employment or business, which Catholic ethics always understands simultaneously as a specific human community. It is a sphere where one must see one's goals in the goals of others, see the moment of need and service directly in one's own profit, where one must learn 'competing in love' and 'unity in conflict' and where, although conflicts are humanly justified, listening to 'estranged neighbours' must prevail. It is also a sphere of life in which one must critically come to terms with the painful tension between freedom and authority, personal self-realisation and economic oppression, injustice and suffering. This tension cannot be removed from human life altogether, but it is nonetheless only the dark side of one's own differential co-responsibility for the business activity and the company as a whole, which is not exhausted by completing one's task, but transcends it by a shared search for the meaning of the work done together in a plurality of views and perspectives. The fourth level of particular economic ethics is the level of so-called 'economic democracy', when one searches for the anthropological connection of one's company with all citizens and humans who are affected by one's work and business. Questions of justice and human rights, sustainability and ecology, cultural identity and respect for the common world that has been given to all for common use also come into account here.

But there is an even deeper connection between ethics and economic rationality. Good husbandry always ultimately means 'exchanging' oneself with God, oneself and others. It is an extremely paradoxical exchange, in which necessity conjoins with freedom, profit with selflessness, struggle with cooperation, and oppressiveness with self-realisation. But it takes place in all moments, when, due to responsibility for oneself, one's family and neighbours, one bears the lot of one's existence in the sweat of one's face and at the same time tries to glimpse in it an imprint of meaning, joy and redeemed humanity. So, Christ's word that the measure we use will be used to measure us is all the more urgent even in the economic sphere. And what cannot be expressed by human measuring will only then perhaps be added to us.

69 Cf. BENEDICT XVI, Verbum Domini (on-line), at: http://w2.vatican.va/content/benedict-xvi/en/apost_exhortations/documents/ hf_ben-xvi_exh_20100930_verbum-domini.html, art.10. 


\title{
Solidary Profit and Efficiency of Love. \\ Motives in Contemporary Catholic Economic Ethics
}

\begin{abstract}
Based on interpreting important currents within contemporary Catholic economic ethics, the paper examines different approaches to overcoming the deficiency of economic rationality in the sphere of morality and the moral deficiency in the sphere of market economy. In that way, it searches for an answer to the key question of whether and in what form economics ethics is possible in contemporary global economic practice and how Catholic social thinking and tradition can specifically contribute to it.
\end{abstract}

Keywords: morality and economy, economic ethics, gift economy, Catholic libertarianism, Catholic social reformism, social market economy, critical realism, micro ethics of company life, global economic crisis, economic-ethical practice, eschatology of economic development, exchange of human freedom

\section{Author contact}

\section{Dr. Vojtěch Mašek}

Charles University

Catholic Faculty of Theology, Department of Theological Ethics and Theology of Spirituality Thákurova 3, 16000 Praha 6

vojtech.masek@seznam.cz 